DOI: 10.17234/SRAZ.65.46

UDK: 81'255.4'373.7

Original scientific paper

Recibido el 26 de abril de 2020

Aceptado para la publicación el 25 de noviembre de 2020

\title{
Los procedimientos de traducción de los fraseologismos y sus funciones dentro de un texto literario
}

\author{
Edina Spahić \\ Facultad de Filosofía de Sarajevo \\ hispadina@gmail.com
}

Con este trabajo pretendemos estudiar algunos aspectos de la traduccićon literaria, en particular tratamos la traducción de las unidades fraseológicas dentro de un texto literario porque en ellas, más que en otras unidades lingüísticas, se reflejan las imprescindibles diferencias culturales. Se van a analizar las diferentes técnicas de traducción y de equivalencia traductológica sobre un corpus definido. Dado que los fraseologismos a menudo nacen dentro de una determinada cultura, su reconocimiento y su correcta interpretación han sido el motivo principal de esta investigación.

Palabras clave: fraseología, traducción, equivalencia traductologica, cultura

\section{Introducción}

Raras veces un lector es consciente del proceso de traducción o del hecho de que las culturas ajenas llegan a conocerse gracias a la traducción que representa el aprendizaje más profundo de ellas. Por eso se hace inevitable pensar en grandes traductores, como, por ejemplo, por mencionar solo algunos nombres, en Albert Bensoussan que tradujo al francés más de veinte obras de Vargas Llosa, o en Claude Couffon, que descubrió los nombres más destacados de las literaturas hispanas al mundo francófono. Según Bensoussan (1966: 41) la traducción "ha de situarse entre dos coacciones: la necesaria fidelidad al texto español y el imprescindible acatamiento a la lengua francesa."

A través de la traducción, Bensoussan ha conocido la obra de Vargas Llosa mejor que cualquier otro lector y con todo derecho se considera a sí mismo la voz francesa de Vargas Llosa, su doble detrás del telón, su escriba admirativo, respetuoso e imitativo.

Octavio Paz (1971) entiende la taducción como transformación del texto original porque Traducción y creación son operaciones gemelas. El traductor es un escritor que crea un texto nuevo (pero ya conocido) en otra lengua y para otro contexto cultural. No es un creador que, como dijo Vargas Llosa, compite con Dios, sino más bien un autor que transforma un texto creando una dimensión nueva del texto original. Es el lector más cauteloso que ocupa un puesto complicado, dentro de 
un marco del que no debería salir, establecido por el autor del texto original cuya libertad no conocía límites.

\section{Formación del corpus y bases teóricas}

El corpus para este trabajo ha sido extraído de dos novelas de Mario Vargas Llosa: La tía Julia y el escribidor, y Travesuras de la niña mala, y sus respectivas traducciones al serbocroata ${ }^{1}$ y serbio.

Se trata de dos novelas escritas en diferentes épocas (1977 y 2006) y traducidas por dos traductoras también en épocas y contextos diferentes.

El espacio geográfico, social y humano tiene mucha importancia en la narrativa de Vargas Llosa:

Me era enormemente útil (no sé si en los hechos, pero, sin la menor duda, psicológicamente, una inyección de energía, volver a oír hablar peruano, escuchar a mi alrededor esos giros, vocablos, entonaciones que me reinstalaban en un medio al que me sentía visceralmente próximo, pero del que cada año perdía innovaciones, resonancias, claves. (TJ:471)

El texto literario (y sus respectivas traducciones) es la mejor base para hacer este análisis por varios motivos, entre otros porque un texto literario nos permite analizar el potencial comunicativo de los frasemas mucho mejor que otros textos.

El trabajo se basa en la concepción amplia de la fraseología, es decir, la disciplina lingüística bajo cuyo paraguas se encuentran agrupan las unidades fraseológicas:

“todos los tipos de unidades fijas, estables cuya característica es la fijeza de sus elementos y el hecho de que no son producidas en el momento de habla sino reproducidas, hechas, y que pertenecen al sistema fraseológico de una lengua dada. Como consecuencia de eso, en el marco de la fraseología deben estudiarse las denominadas y modismos, las frases proverbiales, los refranes y todo tipo de fórmula estable." (Tristá, 1985: 86)

La dificultad de trasladar estas unidades a otra lengua procede de su carácter idiosincrásico, de ahí que Newmark (2006) opine que: "cuanto más cultural (más local, más alejado en el tiempo y en el espacio) es un texto, menor - yo diría que inconcebible - es el efecto equivalente, a no ser que el lector sea imaginativo y sensible y esté empapado de la cultura de la LO." (Newmark, 2006:75)

Para Nord (1991) son problemas específicos del texto en cuestión (figuras del lenguaje, metáforas, palabras inventadas, juegos de palabras).

El proceso de la traducción de la fraseología pasa por cuatro fases, según Corpas Pastor (2003):

1. identificación de la Unidad Fraseológica (UF)

2. interpretación de la UF en el contexto

1 La denominación serbocorata dejó de aplicarse el año 1991 cuando Croacia se independizó. 
3. búsqueda de correspondencias en el plano léxico

4. establecimiento de correspondencias en el plano textual

Estas cuatro fases según Corpas Pastor no implican una sucesión temporal lineal y ordenada. ${ }^{2}$ La autora reconoce diferentes grados de equivalencia "desde la equivalencia funcional hasta las unidades culturalmente específicas de difícil reproducción." (Corpas Pastor 2003:305)

El principal criterio de nuestro análisis ha sido el de la equivalencia fraseológica, es decir, los tres niveles: equivalencia nula, parcial y total. La mayoría de los ejemplos analizados (en total 350), tal y como esperábamos, son casos de equivalencia parcial. Tanto el contexto como el valor comunicativo y pragmático del texto traducido y, por supuesto, las funciones que los frasemas desempeñan determinarán el procedimiento traductológico que se debe aplicar.

Esas funciones son múltiples, la más importante, puesto que se da siempre en todas las unidades fraseológicas, es la función fraseológica: “Consiste en facilitar y simplificar tanto la formulación del mensaje como su recepción o descodificación, puesto que la UF permite decir algo mediante una construcción lingüística ya hecha y conocida en la comunidad respectiva." (Zuluaga, 1997: 631)

Pueden entenderse como garantía de comunicabilidad que permite, de forma eficaz y con cierta economía, transmitir el mensaje que puede tener multiples efectos con sentido diferente como burla, amenaza, ironía, etc.

Otras funciones inherentes de las unidades fraseológicas son:

- función connotativa: marcas dialécticas, sociales, estilistícas;

- función icónica: un número importante de los fraseolgismos se basa en las imágenes. Su importancia es fundamental sobre todo en el proceso de aprendizaje de las lenguas extranjeras.

- función lúdico-poética: los fraseologismos se caracterizan por determinadas características fonoestilísticas como por ejemplo: aliteraciones, rimas paronomasias, paralelismos, repetición etc. El $99 \%$ de los frasemas españoles están estructurados a base de ritmo. ${ }^{3}$

\section{Estrategias y niveles de equivalencia traductológica}

En el caso de lenguas que difieren genéticamene y provienen de culturas geográficamente alejadas, la mayoría de los equivalentes totales son internacionalismos cuya equivalencia total se basa en:

2 “(...) ello dependerá en todo caso del grado de competencia fraseológica del traductor, del grado de equivalencia (total, parcial o nula) del binomio fraseológico y de la complejidad de las relaciones léxicas, semánticas, pragmáticas, discursivas y textuales contraídas por la UF en el contexto del TO."(Corpas Pastor, 2000: 489)

3 Calero Fernández (1991: 73-84) 
- los elementos somáticos y zoónimos

- los fenómenos naturales que se suelen presentar en diferentes culturas

- la religión como la base de su motivación

- la tradición greco-latina

- la literatura universal

- los tópicos racionales, sociales, nacionales y prejuicios

A continuación, teniendo en cuenta el espacio limitado, expondremos tan solo algunos ejemplos de diferentes estrategias de traducción del corpus analizado.

En cuanto a las paremias es muy probable que haya un equivalente total siempre y cuando la unidad no esté culturalmente marcada.

- Quien con fuego juega tarde o temprano termina por chamuscarse. ${ }^{4}(\mathrm{TJ}, 221)$

- Ko se vatrom igra, pre ili kasnije se opeče (TH, 197)

Salvo escasos casos de equivalencia paremiológica total, registramos más casos de equivalencia fraseológica total de otros tipos de estructuras fraseológicas: hablar como un loro [pričati kao papagaj]; no caber ni un alfiler [ne može ni igla stati]; ser el talón de Aquiles [biti Ahilova peta]; construir castillos en el aire [graditi kule u vazduhu].

La traducción literal consiste en traducir palabra por palabra. Los traductores la emplean por la falta de equivalente fraseológico en la lengua meta LM o porque no encuentran un equivalente fraseológico. Veamos algunos ejemplos del corpus:

- Temía las consecuencias de aquel intento de mezclar el agua y el aceite, pero, al final organizó la reunión. (NM, 101)

- Plašio se posledica tog pokušaja da se pomešaju voda i ulje, ali je na kraju organizovao sastanak. $(A N D, 92)$

Mezclar el agua y aceite es una variante (creada por el autor) del frasema mezclar churras con merinas "confundir cosas o conceptos que no tienen nada que ver, aunque parezcan semejantes". El autor ha hecho una manipulación creativa, es decir se trata de desautomatización $n^{5}$ del frasema, procedimiento respetado en el texto meta. La traducción literal en este caso funciona porque la imagen se basa en nuestra experiencia cotidiana, el aceite y el agua se repelen y no pueden mezclarse. En la lengua meta existen dos frasemas con el mismo significado fraseológico: Ne mogu se miješati kruške i jabuke; Ne mogu se miješati krv i sol.

- Si a alguien le convenía aquello de "trabajar por amor al arte" era a Marcela. (NM, 337)

- Ako je nekome pristajala izreka da, "radi iz ljubavi prema umetnosti", to je bila Marcela.

$(A N D, 295)$

Trabajar por amor al arte es una locución verbal cuyo significado fraseológico es: "hacer algo sin aspirar a recompensa. El traductor destaca que el enunciado

4 Este frasema se puede considerar un caso de alteración del frasema.

5 "las variaciones desautomatizadas son creaciones en el acto de habla, o de escritura, que los emplea, y su interpretación cabal depende del texto y el contexto en que se presentan." (A. Zuluaga, 1999:542) 
que procede es una expresión "izreka"de la LO. Es un intento, que debido al contexto en el que aparece, tiene sentido, aunque no asegura la comprensión adecuada por parte del lector meta. El mayor nivel de equivalencia comunicativa podría conseguirse parafraseando, como por ejemplo:

Ako je se za nekoga moglo reći da radi za džaba/badava to je bila Marcela.

\section{Paráfrasis}

A través de este procedimiento no se reproduce la forma del frasema sino que, usando una combinación libre de palabras, con una ocupación léxica totalmente diferente, se intenta trasladar el sentido figurativo del frasema del TO, como en el siguiente ejemplo:

- El primer momento casi me pega una cachetada - confesó la tía Julia, sentándose a mi lado-. (TJ, 443)

- U proom trenutku samo što me nije slepila - priznala je tetka Hulija, sedajući pokraj mene. (TH, 341)

Pegar una cachetada es una locución verbal que no se encuentra registrada en ninguno de los diccionarios consultados, su sinónimo es: pegar una bofetada. Cachetada es un americanismo. El traductor traduce con una combinación libre de palabras omitiendo el lexema cachetada que no tiene su justificación cuando en la LM existe la combinación fija que aparece con frecuencia bastante alta: raspalitil opaliti šamar/pljusku/šljagu "pegar una cachetada".

\section{El empleo de un lexema}

Uno de los procedimientos posibles de traducción es sustituir el frasema de TO con un lexema del TM. Suele ser una traducción neutra con la que se alcanza la equivalencia comunicativa. En el siguiente caso este procedimiento no ha sido el más adecuado:

- El doctor Quinteros, mientras les llevaba la cuerda, pensó - recordando el gimnasio que hoy le tocaba estar en la berlina. (TJ, 44)

- Strpljivo podnoseći njihove šale doctor Quinteros pomisli - sećajući se gimnastičke sale - da mu je danas baš zapalo da se s njim sprdaju. (TH, 35)

Estar en la berlina es una locución adverbial cuyo significado fraseológico es estar en ridículo. El traductor opta por el lexema sprdati "estar de coña" preteneciente al registro vulgar. Proponemos emplear el frasema bit u mašini "estar dentro de la máquina" (da je njegov red da bude u mašini) con una ocupación léxica bastante parecida porque ambos lexemas berlina / mašina pertenecen al mismo campo semántico (son máquinas). De esa manera se consigue mantener la imagen de estar encerrado dentro de una maquina en ambos frasemas. 


\section{Unidades fraseológicas creadas por el autor}

Es muy frecuente en un texto literario encontrar unidades fraseológicas modificadas, alteradas o creadas por el autor. Toda obra literaria, y por consiguiente toda traducción literaria, cuenta con estos ejemplos. En ocasiones a esas manipulaciones se les llama autorismos que con el tiempo consiguen difundirse y ser adoptadas por parte de la comunidad lingüística. Através de este proceso se logran distintos efectos estilísticos. Si se trata de una modificación bien pensada el lector la va a reconocer e interpretar en su sentido figurado. También puede que el traductor falle en su intención por lo cual se produce un efecto de extrañeza en el lector meta. Nuestro corpus también cuenta con tales casos.

- Cuidado que el hijo de Dorita nos vaya a salir del otro lado - se rió la tía Julia y yo sentí un arrebato de solidaridad con su ex marido pero sonreí y le llevé la cuerda. $(\mathrm{TH}, 20)$ - Onda treba da pazimo da nam Dorotin sin ne postane peško - nasmejala se tetka Hulija a ja sam iznenada osetio solidarnost prema njenom bivšem mužu. (TJ, 14)

La combinación libre de palabras del otro lado sirve para evitar la palabra homosexual. El traductor no respeta este eufemismo intencional sino que usa la palabra vulgar para designar a un homosexual. La forma de diminutivo en la que aparece el lexema vulgar no es que suavice la vulgaridad sino le añade un tono bastante despectivo y humillante.

Nuestra solución consiste en emplear una combinación libre de palabras que se acerca bastante al frasema de la LO, postati nastran "convertirse en alguien excéntrico/extraño".

\section{Conclusión}

Según Bensoussan, las traducciones de obras de grandes artistas a primera vista no parecen trabajos complejos:

“Es como el dibujo de Picasso que parece muy evidente, el rasgo del óvalo de una cara de un solo y seguro trazado, mientras que en realidad es el resultado de años de tentativas complejas en las que el artista se aplicó a una reproducción detallista y complicada, para finalmente optar por un sencillo trazo de lápiz tan obvio que uno se dice: ha de ser muy fácil, un niño lo haría."

Aunque en ocasiones la traducción se percibe como un esfuerzo utópico $y$ desesperado, a diario se traducen cantidades enormes de textos empleando estrategias diferentes de las que ninguna puede o debe tener prioridad sobre otra. Todos los procediminetos empleados en las traducciones analizadas son aceptables; eso sí, no todos, como se puede observar, llegan a ser una traducción adecuada. La mayoría son casos de equivalencia parcial alcanzada a través de diferentes estrategias. No siempre se trata de un equivalente al nivel de sistema pero comparte el mismo significado fraseológico, mientras difieren en el aspecto léxico o sintáctico. 


\section{Bibliografía}

Bensoussan, Albert (1966). Marioa Vargas Llosa visto por su traductor al francés. < http://www.trans.uma.es/pdf/Trans_1/trans1-vargasllosa.pdf>

Corpas Pastor, Gloria (2000). Las lenguas de Europa: Estudios de fraseología, fraseografía y traducción. Granada: Comares.

Corpas Pastor, Gloria (2003). Diez años de investigación en fraseología: análisis sintáctico, semánticas, contrastivos y traductológicos. Madrid: Frankfurt am Main, Vervuert.

Newmark, Peter (2006). Manual de traducción. Madrid: Cátedra.

Nord, Christiane (1991). Text analisis in translation: theory, metodology and didactic application of a Model for translation oriented text analysis. Amsterdam: Atlanta, GA.

Paz, Octavio (1971). Traducción: literature y literalidad. Barcelona: Tusquets.

Tristá, Ana María (1985). Fraseología y contexto. La Habana: Editorial de ciencias sociales.

Zuluaga, Alberto (1999). Traductología y fraseología, en: Paremia, 8, pp. 537-549, Madrid.

Zuluaga, Alberto (1997). Sobre las funciones de los fraseologismos en textos literarios, en Paremia, 6, pp.3-13.

Vargas Llosa, Mario (2006). La tía Julia y el escribidor. Punto de Lectura, S.L.

Vargas Llosa, Mario (1998). Tetka Hulija i piskaral. Sarajevo: Svjetlost.

Vargas Llosa, Mario (2008). Avanture nevaljale devojčice. Beograd: Laguna.

Vargas Llosa, Mario (2006). Travesuras de la niña mala. Madrid: Alfaguara Santillana, Ediciones generales S. L.

\section{Diccionarios:}

Buitrago, Alberto (2007). Diccionario de dichos y frases hechas. Madrid: Espasa.

Junceda, Luis (1995). Diccionario de refrenes. Madrid: Espasa.

Matešić, Josip (1982). Frazeološki rječnik hrvatskog ili srpskog jezika. Zagreb: Školaska knjiga.

Pascual, Sauzo (1999). Abecedario de dichos y frases hechas. Madrid, México, Buenosaires: EDAF.

Real Academia Española de la Lengua, (2011). Diccionario de la lengua española. Madrid: Espasa.

Renaud, Richard (2006). Diccionario de hispanoamericanismos no recogidos por la Real Academia Española. Madrid: Cátedra.

Seco, Manuel / Olimpia, Andrés / Ramos, Gabino (2005). Diccionario fraseológico documentado del español actual. Madrid: Aguilar. 


\section{Proces prevođenja frazeologizama i njihova funkcija u književnom tekstu}

U ovom radu cilj nam je ukazati na funkcije frazema u književnom tekstu te na probleme u precesu njihovog prevođenja iz jezika izvornika u ciljni jezik, tj. iz izvorne $u$ ciljnu kulturu. Analizirat ćemo različite tehnike u prevođenju frazeologizama kao i razine frazeološke ekvivalencije. S obzirom da su frazemi često motivirani specifičnom kulturnom tradicijom, pronalaženje ekvivalenata u ciljnom jeziku, ali i njihovo prepoznavanje i ispravno interpretiranje, motivirali su ovo istraživanje. Namjera nam je istaknuti razlike, ali i sličnosti među frazemima u genetski različitim jezicima porijeklom iz geografski udaljnenih kultura. Prevoditeljske kompetencije, a posebno bikulturalnost osobito dolaze do izražaja u prijevodu ovih jezičnih jedinica.

Ključne riječi: frazeologija, kultura, prevođenje, razine frazeološke ekvivalencije 